\title{
Effect of Heat Treatments and SiC Content in the Mechanical Properties and Microstructure of Self-Lubricating Steels
}

\author{
Nicolás Ignacio Araya ${ }^{a}$, Cristiano Binder ${ }^{a}$, Aloisio N. Klein ${ }^{a}$, Gisele Hammes ${ }^{a}$, \\ José Daniel Biassoli de Mello ${ }^{a, b}$, Claudio Aguilar \\ ${ }^{a}$ Laboratório de Materiais, Centro Tecnológico, Universidade Federal de Santa Catarina, Campus \\ Reitor João David Ferreira Lima, s/n , Trindade, 88040-900, Florianópolis, SC, Brazil \\ ${ }^{b}$ Laboratório de Tribologia e Materiais, Universidade Federal de Uberlândia, Av. João Naves de Ávila, \\ 2121, Santa Mônica, 38400-902, Uberlândia, MG, Brazil \\ cDepartamento de Ingeniería Metalúrgica y de Materiales, Universidad Técnica Federico Santa María, \\ Av. España 1680, 2390123, Valparaiso, Chile
}

Received: July 19, 2017; Revised: September 20, 2017; Accepted: October 05, 2017

\begin{abstract}
The objective of the present work was to study the effect of heat treatments in the microstructure, graphite nodules and mechanical properties of self-lubricating steels, to achieve this, self-lubricating steels $\left(\mathrm{Fe}+0.45 \mathrm{C}+4 \mathrm{Ni}+1 \mathrm{Mo} \%_{\mathrm{wt}}\right)$ and additions of 2 and $3 \%_{\mathrm{wt}} \mathrm{SiC}$ were fabricated. They were consequently heat treated in 3 different conditions: martempering at $180^{\circ} \mathrm{C}$ and tempering at $530{ }^{\circ} \mathrm{C}$ and $300{ }^{\circ} \mathrm{C}$ respectively and austempering at $300{ }^{\circ} \mathrm{C}$. Hardness, yield strength, tensile strength and work hardening behavior were studied in as-sintered and heat-treated samples. The microstructure was analyzed by optical microscopy, scanning electron microscopy, Raman spectroscopy and microhardness. The transformation temperatures were determined using dilatometric tests. Results show that the presence of dissolved $\mathrm{Si}$ in the matrix due to $\mathrm{SiC}$ dissociation notably affects the morphology of the microstructure and transformation temperatures also affecting post heat treatment mechanical properties. The structure of graphite nodules produced by $\mathrm{SiC}$ dissociation is nott significantly affected by the heat treatments.
\end{abstract}

Keywords: heat treatment, metal injection molding, plasma sintering, self-lubricating steel.

\section{Introduction}

In engineering a recurrent topic for research is the development of materials with a good combination of mechanical properties, heat resistance, high wear resistance, high corrosion resistance and low specific weight. When such materials are put into contact and relative motion, a tribological component adds up as minimizing energetic and economical losses due to deficient lubrication becomes an important issue for both companies and researchers. For applications were fluid lubrication is unsuitable (extreme temperatures, near vacuum pressures, contamination-free environments, etc) solid lubricants and self-lubricating materials appears to be an appropriate alternative or even the only alternative to operate under such conditions ${ }^{1}$.

Currently several different methods have been developed for the application of solid lubrication, for example, it can be provided by deposited DLC layers ${ }^{2,3}, \mathrm{BCN}^{4}$, polymer based composite layers ${ }^{5}$, etc. Solid lubrication can also be provided by incorporating solid lubricant into the bulk material by powder pressing ${ }^{6,7}$ or Powder Injection Molding (PIM) ${ }^{8}$. In this context the authors of this paper have developed self-lubricating sintered steels produced by Metal Injection

*e-mail: nicolas.araya@labmat.ufsc.br
Molding (MIM) ${ }^{9}$ and studied its mechanical properties and tribological behavior ${ }^{10,11}$. Through MIM it is possible to obtain a fine microstructure consisting of a steel matrix with homogenously distributed graphite nodules. The graphite nodules come from the addition of silicon carbide $(\mathrm{SiC})$ which dissociates into the ferrous matrix leaving rings of stabilized ferrite surrounding a graphite nodule. This $\mathrm{SiC}$ dissociation and graphite formation provides a stock of solid lubricant which forms a fine graphite rich tribo-layer when the material is put into contact and relative motion with another surface, thus providing lubrication ${ }^{12}$. This graphite has been found to be turbostratic ${ }^{13}$ : turbostratic graphite consist of disordered graphene layers with random parallel stacking without three dimensional order ${ }^{14}$. Turbostratic graphite provides lower friction coefficients than crystalline graphite as found by Kumar et al. ${ }^{15}$ this explains the low friction coefficients and wear rates found by previous studies ${ }^{11,16}$ therefore, studying the structural changes in these nodules became relevant to evaluate the feasibility to perform heat treatments and retain or improve the tribological behavior of these materials.

Besides contributing to the formation and degradation of the tribolayer, the microstructure of the metallic surface has a large influence on the tribological behavior of any material as wear resistance depends on the appropriate combination of strength, ductility and fracture toughness ${ }^{17}$. 
However, the effect of the ferritic Si enriched zones in the hardenability, transformation temperatures and mechanical properties have not been studied yet, thus the objective of this work is to study the influence of the heat treatments on the microstructural evolution and mechanical properties of these materials and to determine if such heat treatments have an impact in the structure of the graphite nodules that are part of the microstructure.

To conduct the study sintered self-lubricating steels with a $\mathrm{Fe}+0.45 \mathrm{C}+4 \mathrm{Ni}+1 \mathrm{Mo}$ steel matrix and additions of 2 and $3 \%_{\text {wt }}$. SiC were heat treated and characterized. The objective of the study was to analyze the influence of the heat treatments and $\mathrm{SiC}$ content in the phase transformations, microstructure, graphite nodules, mechanical properties and work hardening of these materials. Work hardening was considered of interest as a high work hardening coefficient have been reported to positively influence the wear resistance under dry sliding conditions in genera $1{ }^{17}$ and, in particular, of ferrous alloys containing graphite nodules ${ }^{18}$ while decreasing friction itself ${ }^{19}$. Graphite nodules structure is also of special interest in regards of the wear resistance and friction coefficient of these materials ${ }^{20}$ so Raman spectra is used as it has proven to be an excellent tool to analyze carbon based materials in terms of crystallinity, bonding and defects ${ }^{21-23}$ being particularly useful to analyze the presence of defects in carbide derived carbons ${ }^{24}$.

\section{Materials and Methods}

Three compositions of sintered steels were used for this study; they consisted of a metallic matrix of $\mathrm{Fe}+0.45 \mathrm{C}+$ $4 \mathrm{Ni}+1 \mathrm{Mo}$ (referred as base alloy) and 2 and $3 \%_{\mathrm{wt}}$ of $\mathrm{SiC}$. Table 1 details the powders used and their specifications.

Three different feedstocks were prepared consisting in a mixture of metallic and ceramic powders and $8 \%{ }_{w t}$ of an organic binder system consisting in paraffin-wax, polypropylene, stearic acid (surfactant), ethylene vinyl acetate copolymer (EVA) and amide wax. The composition of the binder system is presented in table 2 .

A pre-mixture step to homogeneously distribute the binder into the raw material mixture was manually performed using a single container and then the mixing step was done using a

Table 1. Powders utilized in this work.

\begin{tabular}{lcccc}
\hline Element & $\begin{array}{c}\text { Commercial } \\
\text { name }\end{array}$ & $\begin{array}{c}\text { Particle } \\
\text { mean size } \\
(\mu \mathrm{m})\end{array}$ & $\begin{array}{c}\text { Purity } \\
\left(\% \%_{\mathrm{wt}}\right)\end{array}$ & Supplier \\
\hline $\begin{array}{l}\text { Prealloyed } \\
\text { Fe }+0.9 \mathrm{C} \\
(0.45 \text { after } \\
\text { sintering })\end{array}$ & CL-OM & 7.84 & 98.3 & Basf \\
Ni & PF-10F & 6.06 & 99.9 & ATMIX \\
$\mathrm{Mo}$ & OMP & 5.50 & 99.8 & HC \\
$\mathrm{SiC}$ & 800 & 10.0 & 99.0 & Starck \\
\hline
\end{tabular}

Table 2. Binder composition.

\begin{tabular}{lcc}
\hline Element & $\begin{array}{c}\text { Mass \% of the } \\
\text { mixture }\end{array}$ & $\begin{array}{c}\% \text { of the constituent } \\
\text { in the binder }\end{array}$ \\
\hline Polypropylene & 3.40 & 42.56 \\
EVA & 1.32 & 16.51 \\
Paraffin & 2.90 & 36.19 \\
Cocamide & 0.36 & 04.54 \\
DEA & 0.02 & 0.20 \\
Anti-oxidant & $\mathbf{8 . 0 0}$ & $\mathbf{1 0 0}$ \\
Total & & \\
\hline
\end{tabular}

sigma class Haake mixer at $180^{\circ} \mathrm{C}, 70$ RPM for 90 minutes. After the mixing step the now denominated feedstock was crushed using a Seibt blade grinder.

Tests specimens were injected using an Arburg 320S injection molding machine with a closure force of $50 t_{\mathrm{f}}$, table 3 shows the main parameters used during the injection process.

A two-step chemical debinding process was performed to achieve optimal removal of the polymeric components. The first step was chemical dissolution of the lower molecular weight components of the binding system using hexane heated at $55^{\circ} \mathrm{C}$, first by exposing the samples to hexane vapor for 2 hours and then by immersing the samples into a hexane bath for 6 hours. To remove the component with higher molecular weight (polypropylene) the plasma assisted debinding and sintering (PADS) process was used ${ }^{25}$. The PADS reactor allows the control of processing temperatures and heating rates independently of the plasma parameters. The vacuum chamber contains electrical resistance heaters and thermocouples for heating parameters control and electrodes for DC plasma generation. The samples were put over ceramic insulating plates on the structure of the anode and were processed using floating potential plasma. The abnormal hydrogen glow discharge was generated at a pressure of $133 \mathrm{~Pa}$ (1 Torr) and an hydrogen flux of 1000 sccm up to $500{ }^{\circ} \mathrm{C}$. Then a $500 \mathrm{sccm}$ flux was used which consisted into a mixture of $95 \%$ argon ( $99.999 \%$ purity) and $5 \%$ hydrogen ( $99.995 \%$ purity).

After sintering, the samples for microstructural characterization were prepared using standard grinding and polishing procedures and the obtained microstructures were observed using a Leica DM - 4000M optical microscope and a JEOL JSM-6390LV scanning electron microscope with an EDS probe attached for chemical analysis. A solution of Nital 2\% v/v was used to etch the surface of cross-section samples in order to identify the microstructures, however for the samples of base alloy in the as-sintered condition a solution of Picral $4 \% \mathrm{v} / \mathrm{v}$ was used as it allowed for a

Table 3. Powder Injection Molding processing parameters.

\begin{tabular}{lc}
\hline Injection Pressure (bar) & 1000 \\
\hline Settlement Pressure (bar) & 800 \\
Injection Temperature $\left({ }^{\circ} \mathrm{C}\right)$ & 180 \\
\hline
\end{tabular}


better identification of the carbides in the microstructure ${ }^{26}$. For further microstructural characterization micro-hardness measurements using Vickers scale according to ASTM E386 standard with a $10 \mathrm{~g}$ load were performed. A differential dilatometer (NETZSCH DIL 402C) was used to analyze phase changes at heating and cooling. For these tests samples taken from 5 different sintered tensile test specimens were used per alloy, with dimensions of $4.8 \times 10 \mathrm{~mm}$ (diameter $\mathrm{x}$ height) the samples were heated at $950{ }^{\circ} \mathrm{C}$ for $20 \mathrm{~min}$ with a heating rate of $10{ }^{\circ} \mathrm{C} / \mathrm{min}$ and then cooled at a rate of $10{ }^{\circ} \mathrm{C} / \mathrm{min}$ up to $100^{\circ} \mathrm{C}$. To obtain the Raman spectra of the graphite nodules in the samples 3 test specimens per condition were fractured and 5 spectra were obtained using a Renishaw InVia spectrometer with an Ar laser $(\lambda=514.5$ $\mathrm{nm})$ coupled to a Olympus microscope (BX41 TM). To test mechanical properties 5 samples per condition were tested by uniaxial tension at a strain rate of $0.0067 \mathrm{~s}^{-1}$ according to MPIF 42 standard and also 10 Brinell hardness measurements per sample were done using a 2.5 diameter tungsten sphere according to ISO 6506 .

\section{Results and discussion}

Figure 1 presents the microstructure of the samples of base alloy and base alloy $+3 \%$ wi $\mathrm{SiC}$ without heat treatment.
The base alloy in the as-sintered condition shows zones of fine pearlite and ferritic zones with fine precipitated carbides it can be noticed from the figures that when $\mathrm{SiC}$ is added, proeutectoid ferrite surrounding graphite nodules appears. This graphite nodules are formed by carbon coming from $\mathrm{SiC}$ dissociation during sintering, the ferrite rings surrounding them is formed because dissolved $\mathrm{Si}$ (also coming from $\mathrm{SiC}$ dissociation) stabilize $\alpha$-iron in the zones where $\mathrm{SiC}$ was present, this dissolved $\mathrm{Si}$ also inhibits the precipitation of carbides in the microstructure as discussed in references ${ }^{27-29}$ also due to Si presence and the reactor cooling conditions regions of bainite can be found in the microstructure.

All the three alloys had white unetched areas. For the base alloy the etched regions (ferrite + carbides) had a hardness of $2800 \pm 264 \mathrm{MPa}$ and the unetched regions had a hardness of $4400 \pm 500 \mathrm{MPa}$, which corresponds to regions of untempered martensite and austenite due to an incomplete dissolution of nickel.

Fig 2 shows a SEM image of a graphite nodule from the as-sintered sample with $3 \%_{\mathrm{wt}} \mathrm{SiC}$, the figure shows the chemical composition of both the graphite nodule and the area around it which consist in a region with a high amount of carbon surrounded by a metallic phase with a high content of silicon due to $\mathrm{SiC}$ dissociation as it is explained by Binder et al. ${ }^{13}$.

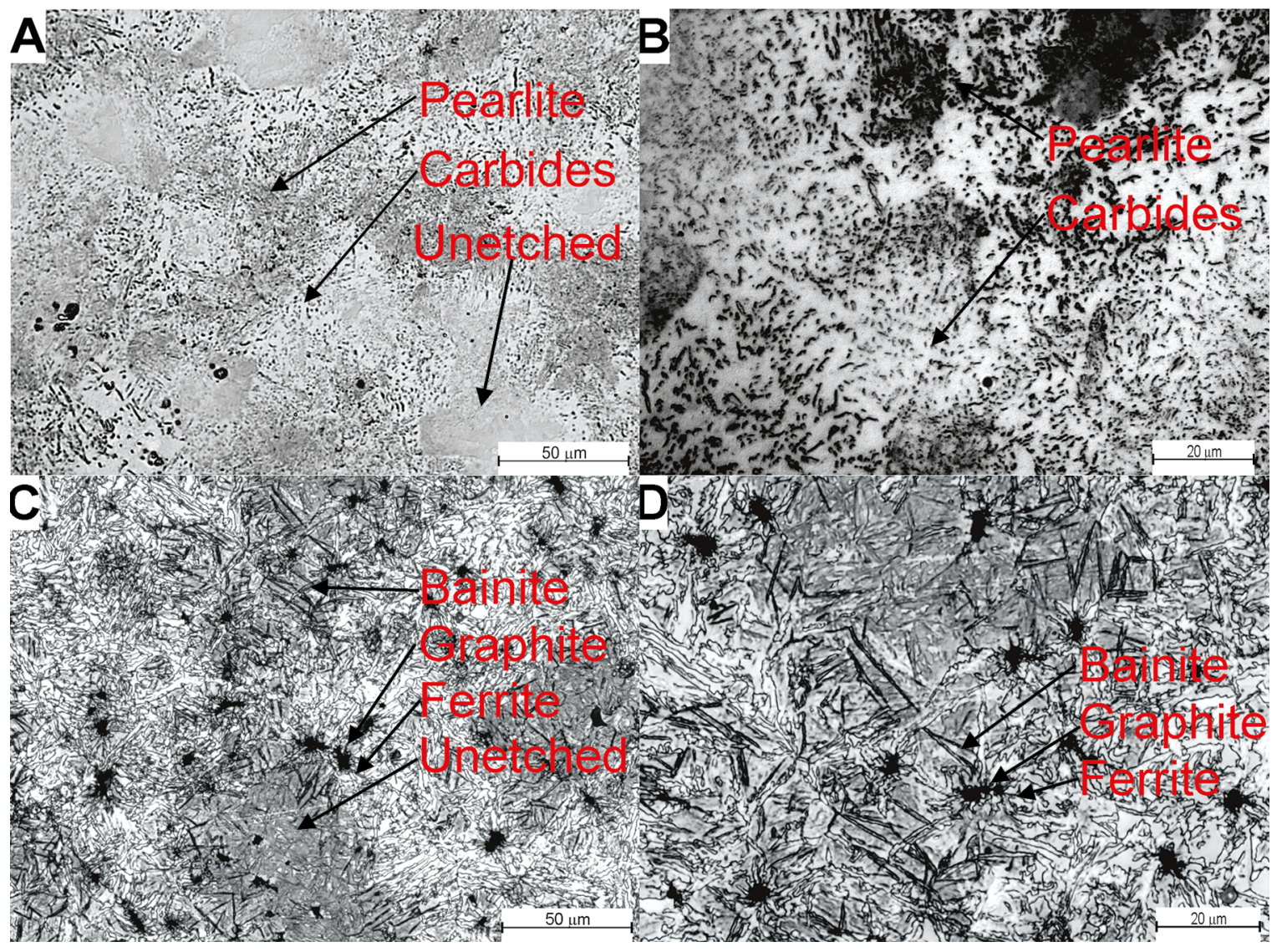

Figure 1. Optical microscopy of the sintered samples corresponding to: (A) and (B) Base alloy, (C) and (D) Base alloy $+3 \%$ siC. 


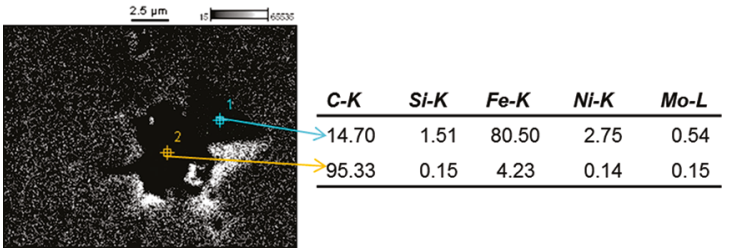

Figure 2. SEM image and EDS analysis of a graphite nodule.

Figs 3 (a) and (b) shows dilatometric curves of heating and cooling for the $\mathrm{Fe}+0.45 \mathrm{C}+4 \mathrm{Ni}+1 \mathrm{Mo}$ base alloys with three different $\mathrm{SiC}$ contents. The analysis shows that the samples with $\mathrm{SiC}$ additions undergo a previous transformation prior to ferrite transformation into austenite, this can be attributed to the tempering of martensite and bainite present in the samples in the sintered condition, being this transformation absent in the samples of base alloy without SiC. There is a slight rise of the tempering the tempering temperature from samples with $2 \%_{\mathrm{wt}} \mathrm{SiC}$ to $3 \%_{\mathrm{wt}} \mathrm{SiC}$, this rise can be attributed to the amount of dissolved $\mathrm{Si}$ in the samples as has been previously discussed by Kozeschnik and Bhadeshia ${ }^{28}$.

Regarding the austenitic transformation, the SiC content decreases the severity of the volumetric change from ferrite to austenite: As part of the microstructure of the SiC containing alloys is stabilized ferrite hence, it doesn't transform into austenite in the $A_{1}-A_{3}$ range. This can be noticed by analyzing the slope of the curves in the $A_{1}-A_{3}$ range, while samples of base alloy exhibit a considerable slope in the austenitic transformation range, samples with $\mathrm{SiC}$ additions shows a narrow range with a minor slope, hence, a less severe volumetric change. The same applies for the transformation from $\gamma$ to $\alpha+\mathrm{Fe}_{3} \mathrm{C}$ during cooling. Also $\mathrm{A}_{1}-\mathrm{A}_{3}$ temperatures are influenced by the $\mathrm{Si}$ dissolved in the matrix as a product of the SiC dissociation during sintering: As Si difficult the transformation of ferrite into austenite $\mathrm{e}^{30,31}$ a rise in the transformation temperatures $\mathrm{A}_{1}$ and $\mathrm{A}_{3}$ is expected. These temperatures are shown in table 4.

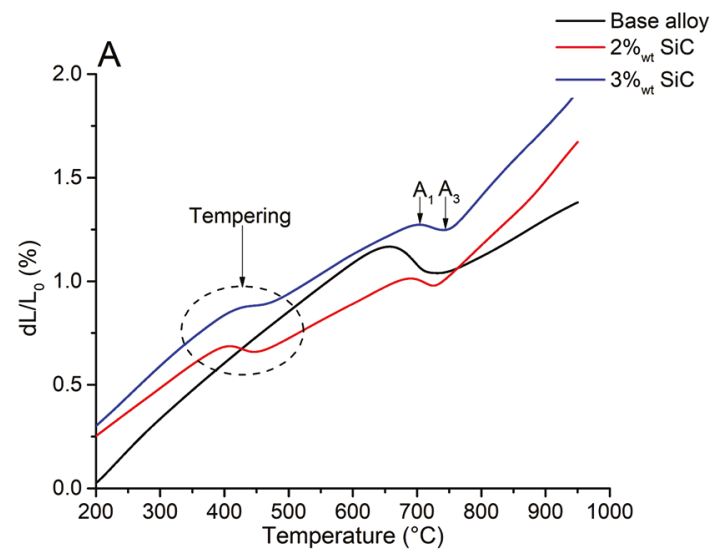

Table 4. Transformation temperatures.

\begin{tabular}{lccc}
\hline & Base alloy & $\begin{array}{c}\text { Base alloy }+ \\
2 \%_{\mathrm{wt}} \mathrm{SiC}\end{array}$ & $\begin{array}{c}\text { Base alloy }+ \\
3 \%_{\mathrm{wt}} \mathrm{SiC}\end{array}$ \\
\hline $\mathrm{A}_{1}\left({ }^{\circ} \mathrm{C}\right)$ & $660+/-6$ & $690+/-6$ & $710+/-5$ \\
$\mathrm{~A}_{3}\left({ }^{\circ} \mathrm{C}\right)$ & $710+/-9$ & $730+/-2$ & $750+/-8$ \\
\hline
\end{tabular}

Silicon dissolved into the matrix due to $\mathrm{SiC}$ dissociation also had an impact in the microstructure of the austempered samples. Figure 4 shows the microstructure of austempered samples containing 0,2 and 3\% $\mathrm{wt}$ SiC. Samples without $\mathrm{SiC}$ shows a regular arrangement of bainite + martensite, however SIC containing samples exhibit larger and coarser bainite grains growing from the ferritic zones surrounding the graphite nodules, this resembles the microstructure found by Malla, Grech and Smallman for high silicon $\mathrm{ADI}^{30}$. Figure 4B and 4D shows a FE-SEM image of bainite from the samples without $\mathrm{SiC}$ and of the acicular ferrite surrounding a graphite nodule of a sample with $3 \%{ }_{w t} \mathrm{SiC}$. As silicon is a ferrite stabilizer it can be expected that acicular ferrite nucleation during austempering starts from the Si rich zones (which in this case is the area surrounding a graphite nodule) and then grow into the retained austenite, this results into a coarser and more unevenly distributed mixture of ferrite-austenite which explains the drop in the mechanical properties of the austempered samples with $\mathrm{SiC}$ additions that is shown in figure 5.

Figure 5 shows the mechanical properties obtained by heat treating samples of the base alloy and samples with additions of 2 and $3 \%$ wt SiC. For all the alloys, as expected, decreasing the tempering temperature increases the mechanical resistance and, in general, the addition of $\mathrm{SiC}$ to the base alloy improves its mechanical properties by increasing the hardness and mechanical strength without a considerable decrease of the ductility. It should be noticed that there are two effects that have to be considered, on one hand the $\mathrm{SiC}$ additions add dissolved $\mathrm{Si}$ to the matrix that

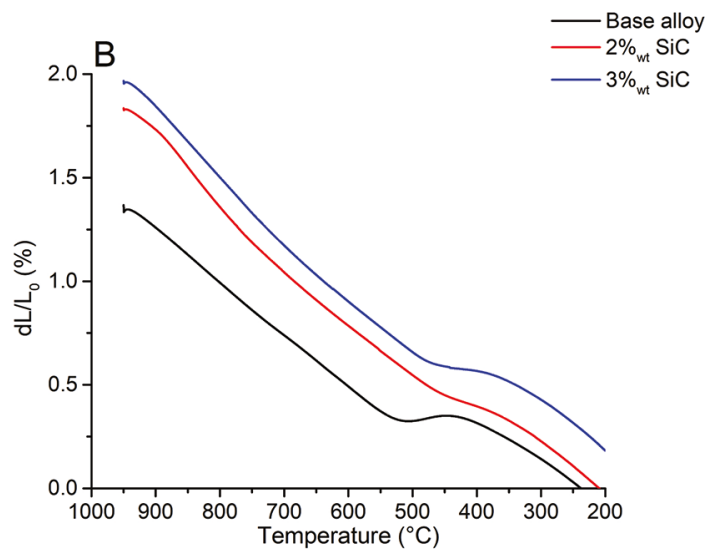

Figure 3. Dilatometric curves of heating (a) and cooling (b). 


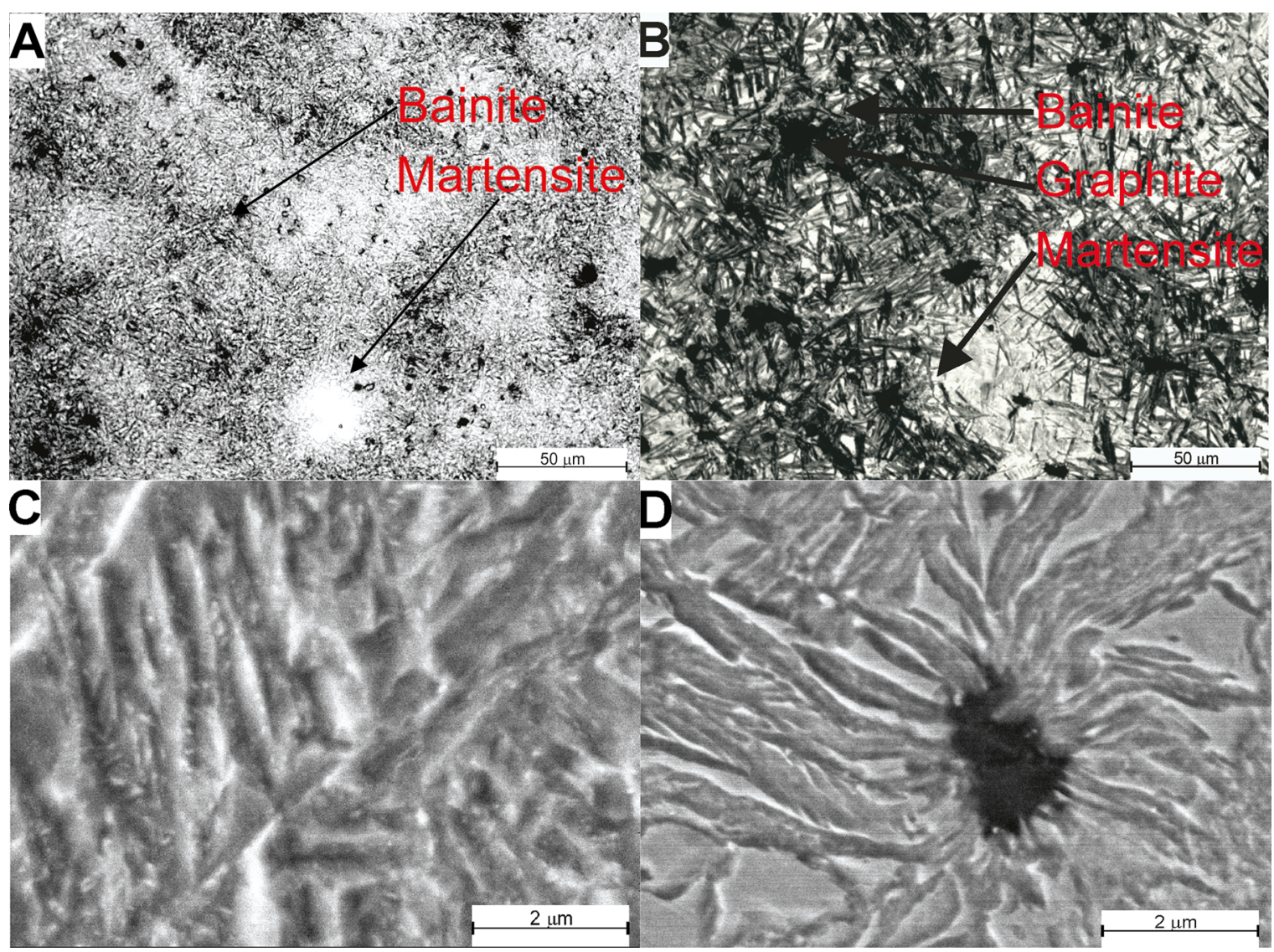

Figure 4. Optical (OM) and electronic (SEM) micrographs of the austempered samples corresponding to: (A) OM of base alloy (B) OM of base alloy $+3 \%_{\mathrm{wt}} \mathrm{SiC}$ (C) SEM of base alloy (D) SEM of base alloy $+3 \%_{\mathrm{wt}} \mathrm{SiC}$.
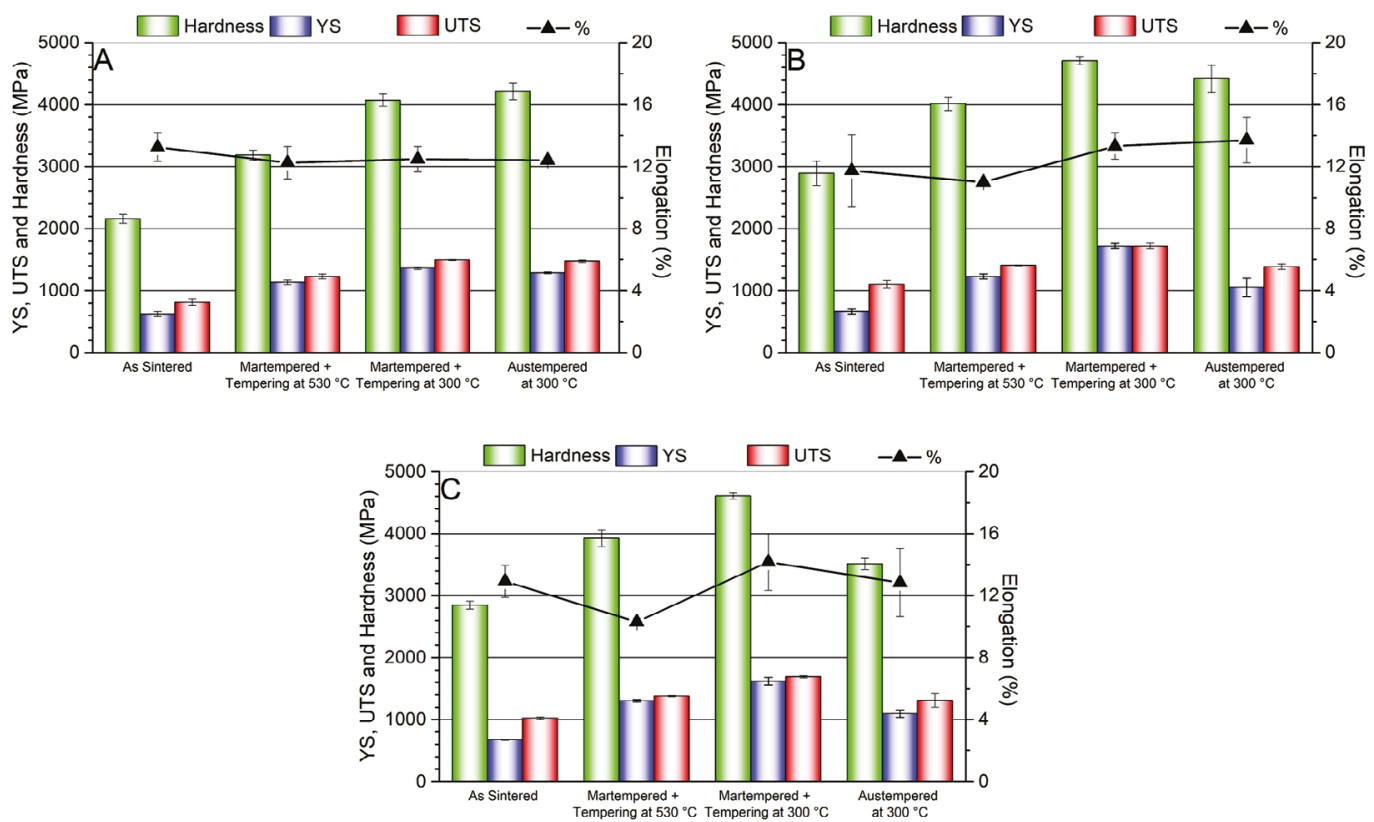

Figure 5. Mechanical properties of as-sintered and heat-treated samples of (A) Base alloy, (B) Base alloy $+2 \%$ wt $\mathrm{SiC},(\mathrm{C})$ Base alloy $+3 \%_{\mathrm{wt}} \mathrm{SiC}$. 
causes solid solution hardening and an increment in the hardenability ${ }^{32}$, on the other hand the zones with a high amount of Si remains ferritic which is ductile ${ }^{33}$ this explaining the positive impact of $\mathrm{SiC}$ in the hardness and ductility. However, for the austempered samples the trend is reversed: without great differences in ductility the hardness and mechanical resistance decreases with $\mathrm{SiC}$ additions. Generally, Si additions into bainite produces an increase into hardness and the other mechanical properties of steels as stated $\mathrm{in}^{34}$ and also reported by ${ }^{35}$. However, as the same austempering treatment were performed in the 3 alloys, disregarding the $\mathrm{SiC}$ content, Si dissolution into the matrix caused a deviation on the kinetics of the bainite formation, therefore resulting into a coarser and less homogenous microstructure which is detrimental to the mechanical properties.

To better understand the effect of $\mathrm{SiC}$ in the mechanical properties of these alloys the work hardening behavior was studied: several work hardening models have been developed to fit experimental stress - strain data into a mathematical model where one or more work hardening exponents can be extracted ${ }^{36}$. The Hollomon equation is regarded as the most simple and practical way to obtain this parameter. The Hollomon work hardening exponent $(n)$ is calculated according to equations 1,2 and 3 :

$$
\sigma=K \varepsilon^{n}
$$

Where;

$$
\text { True Stress } \sigma=S(1+e)
$$

$$
\text { True Strain } \varepsilon=\ln (1+e)
$$

Being $\mathrm{S}$ the engineering stress and $e$ the engineering strain. However a deviation from this behavior had been reported at low and high strains ${ }^{37,38}$. Nevertheless calculations of instantaneous $n$ values over true strain has proven to be a good method to analyze the behavior of steels with mixed microstructures allowing to compare the work hardening exponents and plastic deformation obtained ${ }^{39}$. An instantaneous $n$ value means that the work hardening coefficient is calculated for each step of plastic deformation, this can be deduced from equation (1) as shown by Zhang et al. ${ }^{39}$.

$$
n_{i}=\left(\frac{\varepsilon_{i}}{\sigma_{i}}\right)\left(\frac{d \sigma_{i}}{d \varepsilon_{i}}\right)
$$

Where $n_{\mathrm{i}}, \sigma_{i}$ and $\varepsilon_{i}$ are the instantaneous work hardening exponent, the true stress and true strain respectively ${ }^{39}$. Figure $6 \mathrm{a}, \mathrm{b}$ and $\mathrm{c}$ shows the instant work hardening exponent (n) for $\mathrm{Fe}+0.45 \mathrm{C}+4 \mathrm{Ni}+1 \mathrm{Mo}$ sintered steel with additions of 2 and $3 \%$ SiC under as-sintered, martempered and tempered at $300^{\circ} \mathrm{C}$, martempered and tempered at $530^{\circ} \mathrm{C}$ and austempered conditions.

Instantaneous work hardening exponent v/s true strain plots shows that steels with additions of $\mathrm{SiC}$ exhibits larger plastic strain and work hardening than the base alloy due to the presence of stabilized ferrite and dissolved $\mathrm{Si}$ originated from $\mathrm{SiC}$ dissociation being this effect previously reported by Cai et al. for ferrite-bainite dual phase steels ${ }^{35}$ and by Zhou et al. for ferrite-martensite dual phase steels ${ }^{40}$. The as-sintered and austempered samples show larger strains and work hardening coefficients than the martempered samples, $\mathrm{SiC}$ additions increase these differences thanks to the effect of $\mathrm{Si}$ in the ductility of the alloys as previously discussed.

Raman spectroscopy was used to analyze the influence of the heat treatment in the turbostratic structure of the graphite nodules. Figure 7 shows the Raman spectra of graphite nodules from the base alloy $+3 \%$ siC in the as-sintered and heat-treated conditions. The spectra shows the $\mathrm{G}$ band at $1580 \mathrm{~cm}^{-1}$ which corresponds to a first order mode with $\mathrm{E}_{2 \mathrm{~g}}$ symmetry being typical for graphite materials, the disorder induced bands D and D' at 1360 and $1620 \mathrm{~cm}^{-1}$ respectively which corresponds to double resonance processes which are inhibited in defect-free graphite ${ }^{41}$ and finally the 2D band which is a second order resonance mode which varies with the number of graphene layers and the stacking order of such layers.

Figure 8 shows a 2D band of an as-sintered sample which is adjusted by two Lorentzian peaks, the presence of two peaks within the bands indicates a transition process between a turbostratic structure common to carbide derived carbons (CDCs) to a more crystalline structure which is known to present two well defined peaks within the $2 \mathrm{D}$ band $^{42}$. All the samples show the same peaks, the presence of D and D' bands indicates the presence of defects which is expected in graphitic materials derived from carbides ${ }^{43-45}$. The intensity ratio ID/IG has been largely used to measure crystallite size and to compare the quantity of defects in graphitic samples. Figure 9 shows a plot of ID/IG ratio for the samples in the as-sintered and heat-treated conditions.

Statistical analysis of the ID/IG ratios shows that there is no statistically significant difference between the samples as determined by one-way $\operatorname{ANOVA}(\mathrm{F}(3,56)=1.769, \mathrm{p}=$ 0.05 ) which means that even if the means of the ID/IG ratio differs between conditions it cannot be concluded with a $95 \%$ confidence that the heat treatments had an impact on the structure of the graphite nodules measured by Raman spectroscopy, therefore, for these materials, heat treatments can be used to improve the mechanical properties of these materials without significantly affecting the turbostratic 

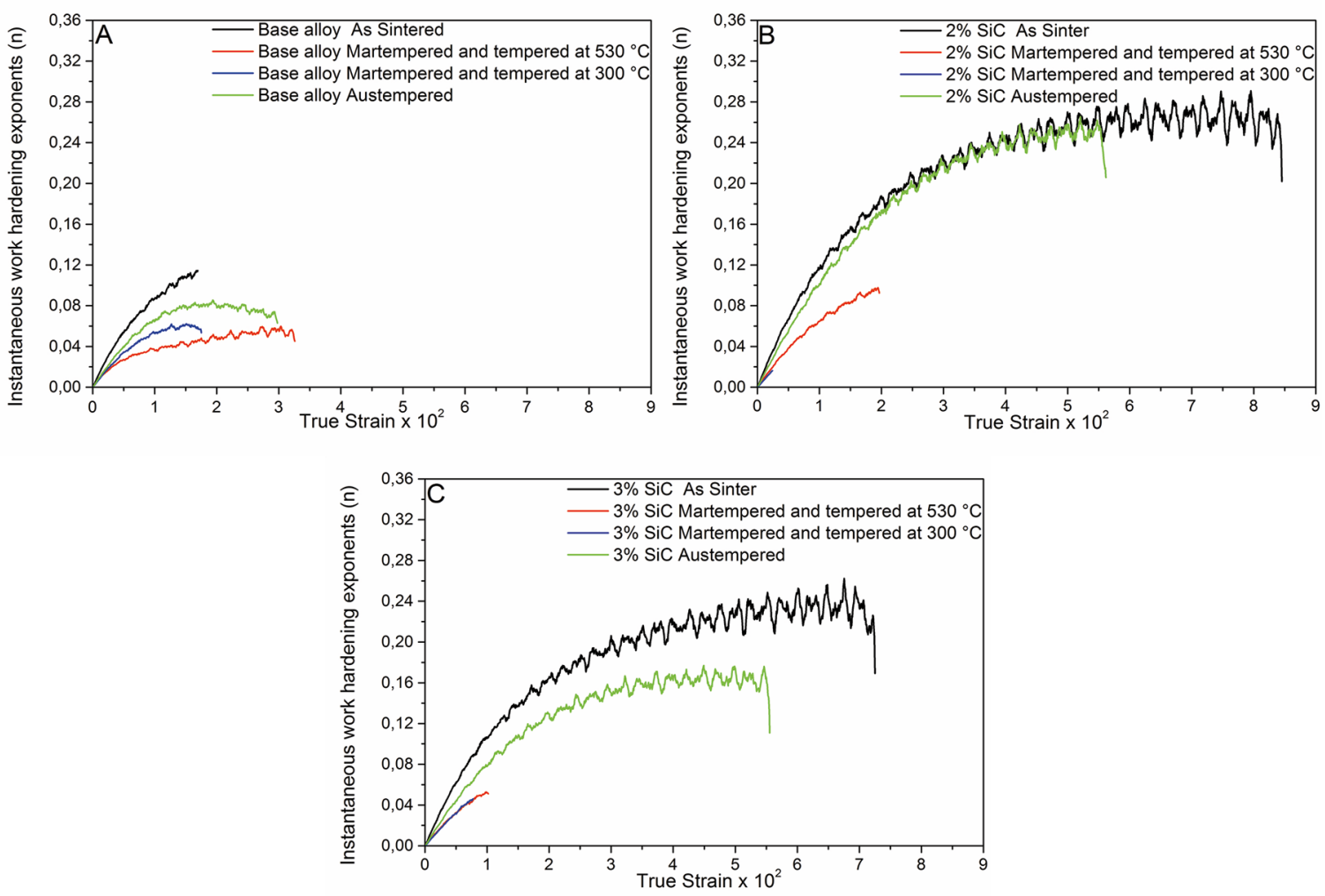

Figure 6. Instantaneous work hardening exponents (n) v/s true strain for: (A) Base alloy, (B) Base alloy $+2 \%_{\mathrm{wt}} \mathrm{SiC}$ and (C) Base alloy $+3 \%{ }_{\mathrm{wt}} \mathrm{SiC}$.

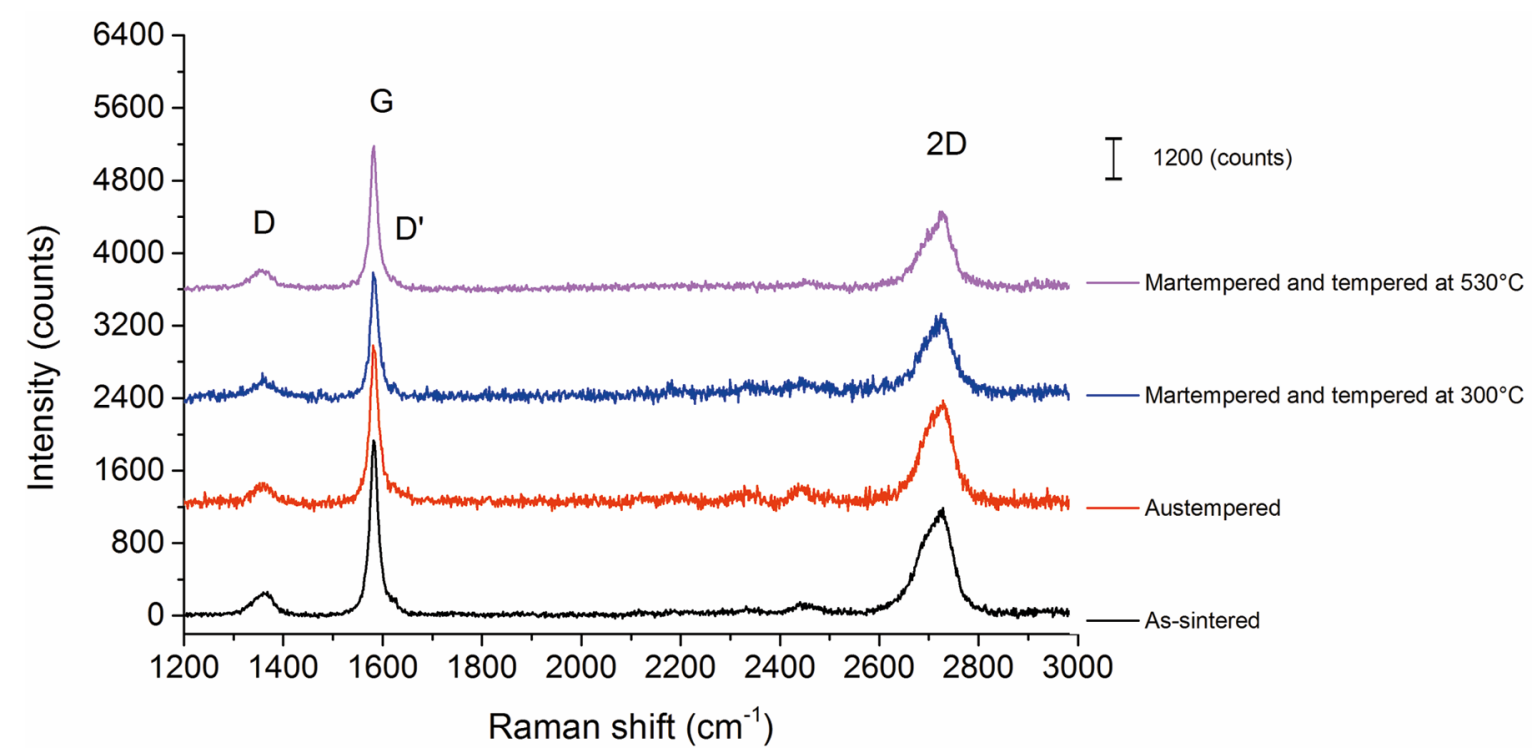

Figure 7. Raman spectra for samples of base alloy $+3 \%_{\mathrm{wt}} \mathrm{SiC}$ in the as-sintered and heat-treated conditions. 


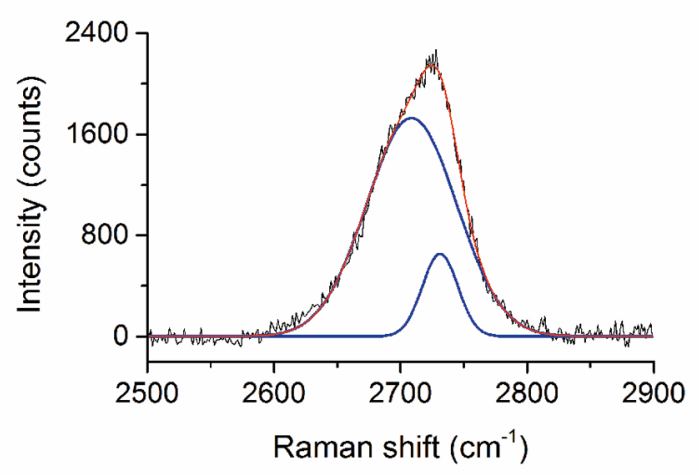

Figure 8. 2D band from a graphite nodule of a sample of base alloy $+3 \%_{\mathrm{wt}}$ SiC fitted by two Lorentzian peaks.

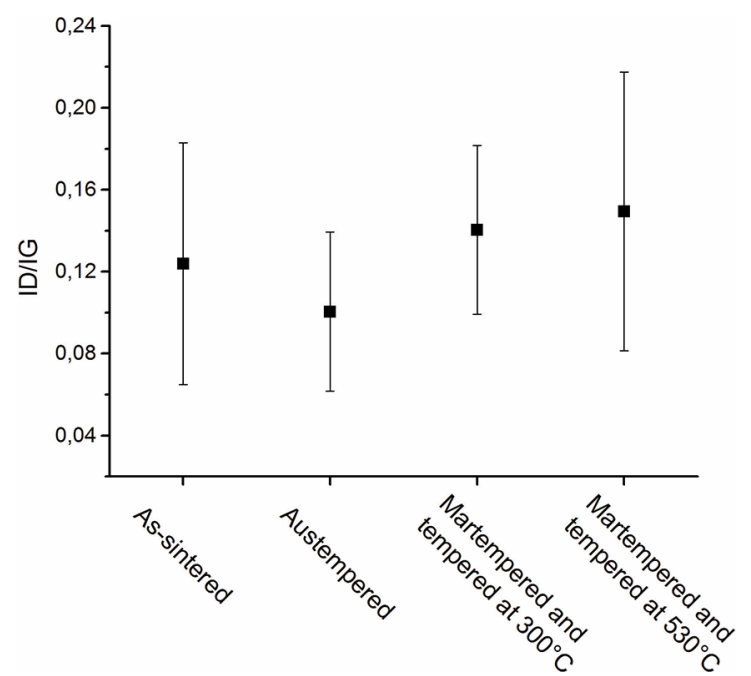

Figure 9. ID/IG ratios for samples of base alloy $+3 \%_{\mathrm{wt}} \mathrm{SiC}$ in the as-sintered and heat-treated conditions.

structure of the graphite derived from $\mathrm{SiC}$ dissociation ${ }^{10}$ thus maintaining its ability to provide solid lubrication ${ }^{16}$.

\section{Conclusions}

Sintered self-lubricating steels were produced by powder injection molding and plasma assisted debinding and sintering. These were heat treated and its mechanical properties and microstructural evolution were studied. From these studies, it was found that:

- $\mathrm{SiC}$ addition to the base alloy decreases the severity in terms of volumetric changes of the transformation $\gamma \leftrightarrow \alpha+\mathrm{Fe}_{3} \mathrm{C}$.

- $\mathrm{Si}$ dissolution into the matrix rises the $\mathrm{A}_{1}$ temperature due to ferrite stabilization, it also modifies the microstructure of the specimens, not only by generating highly stabilized ferrite zones around graphite nodules but also by modifying the morphology of the matrix's microstructure after heat treatment. This is particularly noticeable in the austempered samples where dissolved Si generates coarser bainite grains which are detrimental for the mechanical properties.

- $\mathrm{SiC}$ addition improves mechanical resistance for all the samples with a maximum at $2 \%{ }_{\mathrm{wt}} \mathrm{SiC}$. This trend is reversed for austempered samples as its microstructure is coarser than the one found in the samples without $\mathrm{SiC}$ due to $\mathrm{Si}$ dissolved into the matrix. Also $\mathrm{SiC}$ addition greatly influences the plastic strain and work hardening exponents due to ferrite stabilization and dissolved Si.

- The presence of the D and D' band in the Raman spectra of the graphite nodules indicates the presence of defects and disorder in the structure of these nodules, this is further confirmed by the shape of the 2D band which does not corresponds with a perfectly crystalline graphite.

- Heat treatments don't significantly affect the structure of the graphite nodules generated by $\mathrm{SiC}$ dissociation.

\section{Acknowledgements}

The authors acknowledge the following Brazilian agencies for funding this research: CNPq, Capes, BNDES as well as EMBRACO.

\section{References}

1. Stachowiak GW, Batchelor AW. Solid lubrication and surface treatments. In: Stachowiak GW, Batchelor AW. Engineering Tribology. 3rd ed. Oxford: Butterworth-Heinemann; 2006. p. 419-459.

2. Özmen Y, Tanaka A, Sumiya T. Effect of humidity on the tribological behavior of diamond-like carbon (DLC) film coated on WC-Co by physical vapor deposition method. Surface and Coatings Technology. 2000;133-134:455-459.

3. Zhang D, Shen B, Sun F. Study on tribological behavior and cutting performance of CVD diamond and DLC films on Cocemented tungsten carbide substrates. Applied Surface Science [Internet]. 2010 Feb [cited 2014 Oct 6];256(8):2479-2489. Available from: http://linkinghub.elsevier.com/retrieve/pii/ S0169433209015529

4. Deng X, Kousaka H, Tokoroyama T, Umehara N. Deposition and tribological behaviors of ternary $\mathrm{BCN}$ coatings at elevated temperatures. Surface and Coatings Technology [Internet]. 2014 Oct [cited 2014 Oct 18];259(Pt A):2-6. Available from: http:// linkinghub.elsevier.com/retrieve/pii/S0257897214008706

5. Zouari M, Kharrat M, Dammak M, Barletta M. A comparative investigation of the tribological behavior and scratch response of polyester powder coatings filled with different solid lubricants. Progress in Organic Coatings [Internet]. 2014 Sep [cited 2014 Oct 18];77(9):1408-1417. Available from: http://linkinghub. elsevier.com/retrieve/pii/S0300944014001490 
6. Kato H, Takama M, Iwai Y, Washida K, Sasaki Y. Wear and mechanical properties of sintered copper-tin composites containing graphite or molybdenum disulfide. Wear [Internet]. 2003 Aug [cited 2014 Oct 18];255(1-6):573-578. Available from: http:// linkinghub.elsevier.com/retrieve/pii/S0043164803000723

7. Kováčik J, Emmer S̆, Bielek J, Keleši L. Effect of composition on friction coefficient of $\mathrm{Cu}$-graphite composites. Wear [Internet]. 2008 Jul [cited 2014 Oct 18];265(3-4):417-421. Available from: http://linkinghub.elsevier.com/retrieve/pii/S0043164807007491

8. Furlan KP, Binder C, Klein AN, de Mello JDB. Thermal Stability of the $\mathrm{MoS}_{2}$ Phase in Injection Moulded 17-4 PH Stainless Steel. Journal of Materials Research and Technology [Internet]. 2012 Oct [cited 2014 Oct 18];1(3):134-140. Available from: http:// linkinghub.elsevier.com/retrieve/pii/S2238785412700248

9. Binder C, Hammes G, Schroeder R, Klein AN, de Mello JDB, Binder R, et al. 'Fine tuned' steels point the way to a focused future. Metal Powder Report [Internet]. 2010 May [cited 2014 Jul 30];65(4):29-37. Available from: http://linkinghub.elsevier. com/retrieve/pii/S0026065710701089

10. de Mello JDB, Binder C, Binder R, Klein AN. Effect of precursor content and sintering temperature on the scuffing resistance of sintered self lubricating steel. Wear [Internet]. $2011 \mathrm{Jul}$ [cited 2014 Jul 30];271(9-10):1862-1867. Available from: http:// linkinghub.elsevier.com/retrieve/pii/S0043164811001943

11. de Mello JDB, Binder C, Hammes G, Klein AN. Effect of the metallic matrix on the sliding wear of plasma assisted debinded and sintered MIM self-lubricating steel. Wear [Internet]. 2013 Apr [cited 2014 Jul 30];301(1-2):648-655. Available from: http:// linkinghub.elsevier.com/retrieve/pii/S0043164813000215

12. Schroeder R, Klein AN, Binder C, De Mello JDB. Internal lubricant as an alternative to coating steels. Metal Powder Report [Internet]. 2010 Nov [cited 2014 Jul 30];65(7):24-31. Available from: http://linkinghub.elsevier.com/retrieve/pii/ S0026065711700431

13. Binder C, Bendo T, Pereira RV, Hammes G, de Mello JDB, Klein AN. Influence of the $\mathrm{SiC}$ content and sintering temperature on the microstructure, mechanical properties and friction behaviour of sintered self-lubricating composites. Powder Metallurgy [Internet]. 2016 Nov [cited 2017 Oct 16];59(5):84-393. Available from: https://www.tandfonline.com/doi/full/10.1080/0032589 9.2016.1250036

14. Dresselhaus MS. Future directions in carbon science. Annual Review of Materials Science. 1997;27:1-34.

15. Kumar N, Pandian R, Das PK, Ravindran TR, Dash S, Tyagia K. High-temperature phase transformation and low friction behaviour in highly disordered turbostratic graphite. Journal of Physics D: Applied Physics [Internet]. 2013 [cited 2017 Oct 16];46(39):395305. Available from: http:// stacks.iop.org $/ 0022-3727 / 46 / \mathrm{i}=39 / \mathrm{a}=395305$ ? $\mathrm{key}=$ crossref. b461c093e1da20ee34be913511203890

16. Campos KR, Kapsa P, Binder C, Klein AN, de Mello JDB. Tribological evaluation of self-lubricating sintered steels. Wear [Internet]. 2015 May-Jun [cited 2017 Oct 16];332-333:932-940. Available from: http://dx.doi.org/10.1016/j.wear.2015.01.056

17. Zum Gahr KH. Microstructure and Wear of Materials. Amsterdam: Elsevier; 1987.
18. Bedolla-Jacuinde A, Guerra FV, Rainforth M, Mejía I, Maldonado C. Sliding wear behavior of austempered ductile iron microalloyed with boron. Wear [Internet]. 2015 May-Jun [cited 2017 Oct 16];330-331:23-31. Available from: http:// linkinghub.elsevier.com/retrieve/pii/S0043164815000113

19. Straffelini G, Giuliari C, Pellizzari M, Veneri E, Bronzato M. Dry rolling-sliding wear of austempered cast iron. Wear [Internet]. 2011 Jul [cited 2017 Oct 16];271(9-10):1602-1608. Available from: http://dx.doi.org/10.1016/j.wear.2010.12.018

20. Chun Y, Lim D. Carbide derived carbon: from growth to tribological application. Journal of the Ceramic Society of Japan. 2014;122(1428):577-585.

21. Pimenta MA, Dresselhaus G, Dresselhaus MS, Cançado LG, Jorio A, Saito R. Studying disorder in graphite-based systems by Raman spectroscopy. Physical Chemistry Chemical Physics [Internet]. 2007 [cited 2017 Oct 16];9(11):1276-1291. Available from: http://www.scopus.com/inward/record.url?eid=2-s2.033947263695\&partnerID=tZOtx3y1

22. Jorio A, Souza Filho AG. Raman Studies of Carbon Nanostructures. Annual Reviews of Materials Research. 2016;46:357-382.

23. Cançado LGDOL. Raman spectroscopy of nanographites. [Thesis]. Belo Horizonte: Universidade Federal de Minas Gerais; 2006.

24. Urbonaite S, Hälldahl L, Svensson G. Raman Spectroscopy studies of carbide derived carbons. Carbon. 2008;46(14):1942-1947.

25. Machado R, Ristow W, Klein AN, Muzart JLR, Fredel MC, Wendhausen PAP, et al., inventors; Lupatech S. A., assigneé. Industrial plasma reactor for plasma assisted thermal debinding of powder injection-molded parts. United States patent US7718919 B2. 2010 May 18 .

26. Van der Voort GF. Etching isothermally treated steels. Heat Treating Progress [Internet] 2001 Apr-Jun [cited 2017 Oct 16];1 [8 telas]. Available from: http://www.georgevandervoort. com/images/Metallography-General/Iron-a-Steel/ EtchingIsothermallyTreatedSteels.pdf

27. Bhadeshia HKDH. Lower bainite transformation and the significance of carbide precipitation. Acta Metallurgica. 1980;28(8):1103-1114.

28. Kozeschnik E, Bhadeshia HKDH. Influence of silicon on cementite precipitation in steels. Materials Science and Technolology [Internet]. 2008 Jul [cited 2017 Oct 16];24(3):343-347. Available from: http://dx.doi.org/10.1179/174328408X275973

29. Putatunda SK, Singar AV, Tackett R, Lawes G. Development of a high strength high toughness ausferritic steel. Materials Science and Engineering: A. 2009;513-514:329-339.

30. Mallia J, Grech M, Smallman RE. Effect of silicon content on transformation kinetics of austempered ductile iron. Materials Science and Technolology [Internet]. 1998 [cited 2017 Oct 16];14(5):452-460. Available from: http://www.maneyonline. com/doi/abs/10.1179/mst.1998.14.5.452

31. Mallia J, Grech M. Effect of silicon content on impact properties of austempered ductile iron. Materials Science and Technolology [Internet]. 1997 [cited 2017 Oct 16];13(5):408-414. Available from: http://www.maneyonline.com/doi/abs/10.1179/ mst.1998.14.5.452 
32. ASM International. ASM Handbook, Volume 4. Heat Treating. Materials Park: ASM International; 1991.

33. Davies RG. Influence of silicon and phosphorous on the mechanical properties of both ferrite and dual-phase steels. Metallurgical Transactions A. 1979;10(1):113-118.

34. Bhadeshia HKDH. Mechanical Properties. In: Bhadeshia HKDH. Bainite in Steels. London: Institute of Materials, Minerals and Mining; 2001. p. 285-342.

35. Cai M, Ding H, Lee Y, Tang Z, Zhang J. Effects of Si on Microstructural Evolution and Mechanical Properties of Hotrolled Ferrite and Bainite Dual-phase Steels. ISIJ International. $2011 ; 51(3): 476-481$

36. Hertelé S, De Waele W, Denys R. A generic stress-strain model for metallic materials with two-stage strain hardening behaviour. International Journal of Non-Linear Mechanics. 2011;46(3):519-531.

37. Zhang Z, Zhao W, Sun Q, Li C. Theoretical calculation of the strain-hardening exponent and the strength coefficient of metallic materials. Journal of Materials Engineering and Performance. 2006;15(1):19-22.

38. Kim JH, Kim D, Han HN, Barlat F, Lee MG. Strain rate dependent tensile behavior of advanced high strength steels: Experiment and constitutive modeling. Materials Science and Engineering: $A$ [Internet]. 2013 Jan [cited 2017 Oct 16];559:222-231. Available from: http://dx.doi.org/10.1016/j.msea.2012.08.087
39. Zhang J, Ding H, Misra RDK. Enhanced strain hardening and microstructural characterization in a low carbon quenching and partitioning steel with partial austenization. Materials Science and Engineering: $A$ [Internet]. 2015 Jun [cited 2017 Oct 16];636:53-59. Available from: http://inkinghub.elsevier.com/retrieve/pii/S0921509315003469

40. Zhou L, Zhang D, Liu Y. Influence of silicon on the microstructures, mechanical properties and stretch-flangeability of dual phase steels. International Journal of Minerals, Metallurgy, and Materials. 2014;21(8):755-765.

41. Ferrari AC, Robertson J. Interpretation of Raman spectra of disordered and amorphous carbon. Physical Review B (Condensed Matter and Materials Physics). 2000;61(20):14095-14107.

42. Jorio A. Raman Spectroscopy in Graphene-Based Systems: Prototypes for Nanoscience and Nanometrology. ISRN Nanotechnology. [Internet]. 2012 [cited 2017 Oct 16];2012:234216. Available from: http://www.hindawi.com/journals/isrn. nanotechnology/2012/234216/

43. Li D, Zeng X, Yang Y, Yang J, Yuan W. Freestanding graphene in large quantity prepared by Nickel catalyzed decomposition of $\mathrm{SiC}$ powder. Materials Letters [Internet]. 2012 May [cited 2017 Oct 16];74:19-21. Available from: http://dx.doi.org/10.1016/j.matlet.2012.01.057

44. Dash RK, Nikitin A, Gogotsi Y. Microporous carbon derived from boron carbide. Microporous and Mesoporous Materials. 2004;72(1-3):203-208.

45. Welz S. Identification of carbon allotropes in carbide derived carbon using electron microscopy. [Thesis]. Chicago: University of Illinois; 2003. 